Franz-Josef Arlinghaus

\title{
Point of Reference
}

\section{Trust and the Function of Written Agreements in a Late-Medieval Town*}

in: Strategies of Writing. Studies on Text and Trust in the Middle Ages (Papers from "Trust in Writing in the Middle Ages", Utrecht, 28-29 November 2002), ed. by Petra SchUlTE Marco Mostert and Irena van Renswoude (Utrecht Studies in Medieval Literacy 13) Turnhout 2008, S. 277-299.

"When I attempted once to negotiate the price of chocolate with a saleslady, I found that instead of arguing, she repeatedly pointed to the price tag on which the price was clearly written.” N. LuHMAnN, Social Systems (Stanford, Cal., 1995), p. 428, note 53.

1 Introduction

2 Historical frame

3 Placing texts in the discourses of the city

4 Trust in Writing 1: Trust in an ink-on-paper fixed content?

4.1 Content of the statutes

4.2 Role of the scribes and the role of the city council

5 Trust in Writing 2: Being able to point to something

5.1 'To refer to' - communicating by reference

5.2 Text-reference in practice: A rebellious councilman

6 Late-medieval text-status compared

7 Outlook

8 Bibliography

\section{Introduction/Abstract}

This article concentrates on the $14^{\text {th }} / 15^{\text {th }}$ century uses of writing in an urban environment. Side glances on its use during the High Middle Ages, as well as in present times, are necessary. The first theses is not that the content, but the possibility to refer to a written document, may be seen as the core element of 'trust in writing'. Using this a starting point, a central problem of medieval writing becomes apparent: the status of written texts. Since refering to something prerequisites that this exists by its own right, if a document wants to serve as point of reference, an 'autonomous' status must be attributed to it. Contrary to present times, where writing per se is considered 'independent', during the Late Middle Ages, the status of writing is ambiguous. In taking up Jan Assmann's concept of ‘canonisation' with my second theses, I suggest that late medieval texts had to be 'made' independent in order to function as reference points. The analysis of the prologue of the Cologne statutes, and the so called 'Verbundbrief', will demonstrate how this is done. Examining a conflict within the Cologne city council, I try to show that here texts primarily serve as points of reference, rather than to support the content of an argument that was put forward. Finally, on a more general scale, it is dis-

\footnotetext{
* The article is in part based on the German text 'Rituelle und referentielle Verwendung von Schrift. Textgebrauch in der spätmittelalterlichen Stadt', in 'Frühmittelalterliche Studien’ 38 (2004), 393-413.
} 
cussed what the late medieval society might have gained by using writing in this way. It is suggested that in establishing independent texts as points of reference, the Late Medieval society may have found a new common ground on which to operate.

\section{Historical frame}

With about 50,000 inhabitants, Cologne in the $15^{\text {th }}$ century was probably the biggest city in the German-speaking world. After the battle of Worringen in 1288, Cologne became de facto a more or less independent City, forcing the archbishop of Cologne, de jure still the lord of the city, to stay outside. His influence had been reduced on appointing the jury and the judge of the cities high court, but which in every-day practice was controlled by the city council. However, the archbishops did not give up their attempts to regain power over Cologne until the end of the $18^{\text {th }}$ century ${ }^{1}$.

Similar to many other German cities ${ }^{2}$, the second half of the $14^{\text {th }}$, and the early years of the $15^{\text {th }}$ century was the time of severe internal conflicts. In Cologne, after an uprising in 1370/71, the revolt of 1396 led to great changes in the political system of the town. Prior to this, only certain families could nominate their members to the city council. Now, the council was elected by the so-called 22 'Gaffeln', guild-like associations, in which everybody was committed to becoming a member'.

During the $15^{\text {th }}$ century, we do not find the ever-tense situation of the second half of the $14^{\text {th }}$ century, but troubles between city council, the archbishop-appointed jury of the high court, and even the archbishop himself, persisted. Soon, the new city council behaved as the old did, and the riots of 1481 und 1513 show that the council and citizens (Rat and Gemeinde) did not always live in harmony ${ }^{4}$.

1 For a quick overview of the history of Cologne see B. DREHER (Ed.), Texte zur Kölner Verfassungsgeschichte, (Köln, 1988: Veröffentlichungen des Kölnischen Stadtmuseums 6), p. 9ff.. Dreher also gives a number of texts, important for the political situation of the city (for instance, the 'Verbundbrief', see below).

2 See, for instance, I. BAUMGÄRTNER, 'Niederhessen in der Krise? Städtischer Aufruhr im landgräflichen Kassel und im erzbischöflichen Hofgeismar', in: Nordhessen im Mittelalter. Probleme von Identität und überregionaler Integration, ed. I. BAUMGÄRTNER a.o., (Marburg, 2001), p. 137ff.. A collection of revolts gives E. PITZ, Bürgereinung und Städteeinung. Studien zur Verfassungsgeschichte der Hansestädte und der deutschen Hanse (Köln u.a., 2001: Quellen und Darstellungen zur hansischen Geschichte, N.F. 52), p. 65ff..

3 See the books of W. HERBORN, Die politische Führungsschicht der Stadt Köln im Spätmittelalter (Bonn, 1977: Rheinisches Archiv 100); K. Militzer, Ursachen und Folgen der innerstädtischen Auseinandersetzungen in Köln in der zweiten Hälfte des 14. Jahrhunderts (Köln, 1980: Veröffentlichungen des Kölnischen Geschichtsvereins 36) and G. SCHWERHOFF, 'Apud populum potestas? Ratsherrschaft und korporative Partizipation im spätmittelalterlichen Köln', in: Stadtregiment und Bürgerfreiheit. Handlungsspielräume in deutschen und italienischen Städten des Späten Mittelalter und der Frühen Neuzeit, ed. K. SCHREINER a.o., (Göttingen, 1994: Bürgertum. Beiträge zur europäischen Gesellschaftsgeschichte 7), p. 188ff.

4 For literature see footnote 3 and: G. SCHWERHOFF, 'Die goldene Freiheit der Bürger. Zu den Bedeutungsebenen eines Grundwertes in der Stadtkölnischen Geschichte (13.-17. Jahrhundert)', in: Stadtregiment und Bürgerfreiheit. Handlungsspielräume in deutschen und italienischen Städten des Späten Mittelalter und der Frühen Neuzeit, ed. K. SCHREINER a.o., (Göttingen, 1994: Bürgertum. Beiträge zur europäischen Gesellschaftsgeschichte 7), p. 94.; B. DREHER, 'Die Beschwörung der Freiheit. Gemeinde versus Rat 1481/82, 1512/13, 1525, 1680-86', in: Der Name der Freiheit 1288-1988. Aspekte Kölner Geschichte von Worringen bis heute, ed. W. SCHÄFKE, (Köln, 1988), p. 445ff. 


\section{Placing texts in the discourses of the city}

Cologne produced two important constitutional-like texts during the late middle ages: The socalled Verbundbrief of 1396, and the Statutes of 1437. The Verbundbrief can be seen as a kind of document of unity after the troubles of 1396; a kind of 'Magna Carta' or constitution. All 22 Gaffeln put their seals on this text written on parchment, which contains short but decisive regulations ${ }^{5}$. In contrast, the Statutes of 1437 are a text of considerable length; some 75 pages in the edition of Walther Stein ${ }^{6}$. The statutes are of special interest here, because they themselves give detailed information about who is responsible for the text, and how.

A great part of the text consists in regulations already written down in different protocol books of the $14^{\text {th }}$ and early $15^{\text {th }}$ century; only some of the statutes are new or at least could not be found elsewhere. After a prologue, we find a whole range of different information, starting from which kind of honours are to be offered to the king or the archbishop on their visit to Cologne, down to how much the city courts are allowed to charge for different cases brought before them.

Besides the fact that these statutes are regarded as one of the most important texts of this kind written in Germany during the given period ${ }^{7}$, I have chosen it mainly because of its prologue.

\section{Prologue of the Cologne-Statutes, $15^{\text {th }}$ June $1437 \mathrm{y}^{8}$}

1 Wir burgermeistere ind raet der stat Coelne doin kunt zo ewiger gedechtenisse ... Wilche gesetze ind ordinancie ind alle punten daeinne begriffen wir mit guder moissen gesien ind gehoirt ind unss ['institutions' involved:] mit allen reeden ind vierindviertzigen, vort mit greven ind scheffenen des hoen gerichtz ...

5 gemeynlichen darup foider beraeden ind gutlichen undersprochen hain, ind sijn alle sementlich ind eyndrechtlich sonder yemans wiederachten ... overkomen ind eiyns worden dieser punten hernae beschrieven, [period of validity:] die wir ouch zo ewigen dagen vaste, stiede ind unverbruchlich bynnen unser stat ind gebiede gehalden haven willen .... [no changes to the text are allowed:] Ind so wanne

10 achter dieser zijt voran eyn $\mathrm{n}$ एwe raet unser steide ingaende wirt, so sall hey diese naegeschrieven gesetze ind ordinancie ... bij synen eyden ind truwen egrijffen stiede ind fast zo halden ind die nyet zo kurten off zo lengen noch yed anders darin zo brechen off zo dragen zo laissen in eyncher wijs, [for changes, all institutions have to be asked:] id en geschie dan mit eyme gantzen volkomenen

5 M. Huiskes, 'Kölns Verfassung für 400 Jahre: Der Verbundbrief vom 14. September 1396', in: Quellen zur Geschichte der Stadt Köln, Bd. 2: Spätes Mittelalter und Frühe Neuzeit (1396 - 1794), ed. J. DEETERS a.o., (Köln, 1996), p. 1ff., with translation in modern German and further literature.

6 W. STEIN, Akten zur Geschichte der Verfassung und Verwaltung der Stadt Köln im 14. und 15. Jahrhundert Bd. 1, 2 Bde. (Bonn, 1893: Publikationen der Gesellschaft für Rheinische Geschichtskunde 10), Nr. 331, pp. $631 \mathrm{ff}$.

7 See U. HePpeKAUSEN, Die Kölner Statuten von 1437. Ursachen, Ausgestaltung, Wirkung (Köln - Weimar Wien, 1999: Rechtsgeschichtliche Schriften 12), p. 255ff.. In his thesis, Heppekausen gives an excellent interpretation of the juridical aspects of the statutes.

8 STEIn, Akten 1 , Nr. 331, pp. 631ff. Three different prologues in different copies came to down to us. I am analysing what the editor called 'Vorrede I' (prologue I), because this is most likely the prologue of the manuscript that was used by the city council (with numerous notes of the city scribes at the margin and other signs of intensive use). For a detailed description see STEIN, Akten 1, p. XCIIIff. 
gesprieche ind verdrage aller reede ind der vierindviertzigen, vort greven ind scheffenen des hoen gerichts ... [scribes watch over the statutes:] Ouch so soilen unser steide prothonotarius ind secretarii, die in unser raetzkameren bij eyme raede zertzyt unser steide nu synt ind naemails komende werden, zen heyligen sweren, off sij zu eyncher zyt in raetzstat up eynche sachen sprechen hoerten, die wieder diese nageschrievenen unse gesetze ind ordinancie weren, dat sij dan zerstunt den reat zertzijt, die darup sprechende wurde, daeinne underwijsen ind dieser selver unser gesetze ind ordinancien ermanen soilen, up dat die die vesticlicher ind gedechtnisse gehalden werden.

In the first lines cited here - the prologue in total over two pages long - name the persons and institutions that passed, or better, agreed on these statutes: The two majors of the city, the City council (line 1), the council of the 44, and the jury of the high court with their chief judge (Greve, line 3f.). It is a way of legitimising the statutes, which goes far beyond what would have been necessary in a juridical sense. Together, these institutions wanted that the statutes should be valid almost for ever (line 8), and that the text might not be changed (line 9ff.). If any changes had to be made, all the above mentioned groups had to assemble again and give their agreement (line 14ff.). As part of their oath of office, the scribes of the city had to swear hence forth, that they would watch that the city council did not deal with matters which are against the statutes (line 16ff.). If the scribes were only to hear of a councillor talking on such matters (line 19: in raetzstat up eynche sachen sprechen hoerten), they should warn him to obey the rules. In fact, in the margin of the copy of the statutes that was kept in the town hall, we read nota de secretarijs, written by Johannes Bruwers, one of the two most important scribes working for the city during the first half of the $15^{\text {th }}$ century ${ }^{9}$.

Now almost every prologue of a medieval text tells us something about how a text came into being. But this one is far more explicit than most of the prologues of statutes written at that time in Germany, and what is more, it offers some interesting details about the status and place of the statutes within the mostly oral communication within the city council.

\section{Trust in Writing 1: Trust in an ink-on-paper fixed content?}

\subsection{Content of the statutes}

What made it so attractive to collate all these laws and regulations in writing? It is, of course, quite useful, for instance for the juries and judges, to have all relevant regulations put together in one book ${ }^{10}$. But as has already been mentioned, the statutes lack information of important areas of law in such a city. For instance there are only few regulations on mortgages and debt to be found ${ }^{11}$. The ways of how to lodge an appeal from the city court to the jury of the bishop's high court could be looked up in a number of protocol books, but not in the statutes. This, of course, has a political background ${ }^{12}$, but it shows that on a large scale,

9 STEIN, Akten 1, Nr. 331, S. 633, fn. h.

10 For insights in form and structure of statutes - although concentrating on Italian examples - see H. KELLER a.o. (Ed.), Statutencodices des 13. Jahrhunderts als Zeugen pragmatischer Schriftlichkeit. Die Handschriften von Como, Lodi, Novara, Pavia und Voghera, (München, 1991: Münstersche Mittelalter-Schriften 64).

11 HePPEKAUSEN, Kölner Statuten 1437, p. 255f.

12 Stein, Akten 1, p. XCIVf.; HePPEKAUSEN, Kölner Statuten 1437, p. 36ff. 
one still has to rely on knowing what is usually the case (and what is known and remembered by the people), than on consulting this book ${ }^{13}$.

As could be seen with so many other medieval documents, the content of the text is in large parts incomplete, and sometimes it is not clear what is really meant. And these uncertain sections of the statutes are precisely those which are most likely to become a matter of debate between different groups within the city. The conclusion to be drawn is that although there was a certain trust in the content of the statutes, its main function was probably not to offer a compendium-like text ${ }^{14}$.

\subsection{Role of the scribes and the role of the city council}

As mentioned above, not the city council, but the 'protonotarius' - the main city scribe - together with his secretarii (other city scribes working in his office) were to tell whether new laws henceforth discussed in the council, or even suggestions made by a councillor, would be in accordance with the statutes. At first glance, it seems that pragmatic reasons were to be made responsible for such a proposal: The scribes had the text ready on demand; they were familiar with its content ${ }^{15}$. However, it is quite astonishing that the council attributed the task of interpreting this important text not to one of the councilmen. In fact, the office of the so called 'Ratsmeister', two councillors that had to chair the meeting of the city council, would have been perfect for taking on that task. Even during the $14^{\text {th }}$ century, they had to take care that the sworn oaths, written down in so called 'oath books', were observed by other members of the council ${ }^{16}$.

Of course, the risk that the scribes would interpret the text in a manner unwelcomed by the council was very low. Would they bite the hand that was feeding them? On the other hand, one can well imagine a situation whereby the council is divided into factions and the interpretation of the scribes would become the factor that tipped the scales. However, the city council runs a certain, if low risk, in leaving the interpretation of the statutes to the scribes.

The statutes are a long and sometimes complicated text. Is the main reason for the exceptional position of the scribes that 'text experts' were needed? And would the employment of such 'experts' have fostered 'trust in writing'? The combination of written texts and specialist

13 HePPEKAUSEN, Kölner Statuten 1437, p. 255f.

14 Comparing a number of similar writings of that kind from various cities, Arndt Mihm states that none could claim to be sufficiently complete and systematised or close enough to the problems they should help to solve. He concludes that for the maintenance of public order, the leaders of the (German) towns considered 'oral norms', known by everyone, as sufficient (“die städtische Führung [empfand] für die Aufrecherhaltung der öffentlichen Ordnung ... die Praxis mündlicher Rechtssetzung als ausreichend“). For internal use, however, ephemeral recordings (protocol books) were enough to serve the needs; A. MinM, 'Vom Dingprotokoll zum Zwölftafelgesetz. Verschriftlichungsstufen städtischer Rechtstradition', in: Schriftlichkeit und Lebenspraxis. Erfassen, Bewahren, Verändern. Akten des Internationalen Kolloquiums (8.-10. Juni 1995), ed. H. KELLER a.o., (München, 1999: Münstersche Mittelalter-Schriften 76), p. 44ff., citation p. 47.

15 Two scribes, Sibert von Eilsich and Johann von dem Walle, took part in the commission that prepared and discussed the text; these two actually compiled it; STEIN, Akten 1, p. XCIII and Nr. 331, Vorrede II, pp. 634f..

16 F. LAU, Entwicklung der kommunalen Verfassung und Verwaltung der Stadt Köln bis zum Jahre 1396 (Bonn, 1898: Preisschrift der Mevissen-Stiftung, gekrönt und hg. von der Gesellschaft für Rheinische Geschichtskunde 1), p. 110f. 
explanation should mean a widespread phenomenon, especially these days (consider the judges and the high courts). In contrast to the councillors who, if at all, visited Universities for only a short period of time without gaining a degree ${ }^{17}$, the Cologne scribes, like in many other cities of the $15^{\text {th }}$ century, were university-trained people, often jurist that would sometimes hold a doctors' degree ${ }^{18}$. On the other hand we do know that quite often even today courts interpret laws in this way, while just five years ago, the same court understood the same text precisely the other way around. Asking an expert to find out about the meaning of a text is probably not the best idea if you want to foster 'trust in writing' - i.e- if 'trust in writing' means trust in a once and for ever fixed content of a text ${ }^{19}$. Rather, that the prologue does not want the Ratsmeister, but the scribes to play the role as 'guards' of the text is probably owed to the fact that they were not members of the city council. Formally speaking, the text is thus entrusted to an 'independent' social institution, putting a distance between the 'author/client' of the text (the council) and the persons who are responsible for its application ${ }^{20}$.

From a legal point of view, it would have been sufficient that the council alone would have pronounced the new statutes. To allow the wider city council, the council of the 44 , and the jury of the archbishops court, together with the judge (Greve) to participate is, of course, a clever political move. New here though, is the explicit self-binding of the city council to the text, and the way this should be implemented (the decisive role of the scribes was already highlighted).

Altogether, and according to the prologue, we can see that the most important institution of late medieval Cologne quite obviously restrains itself when it comes down to who is responsible for writing the most important constitutional text of the $15^{\text {th }}$ century. Modesty is a virtue, but a virtue seldom found among politicians, even of the late middle ages. I do not

17 Why the councils had such reservations in accepting people with a university degree is a matter of debate; K. WRIEDT, 'University Scholars in German Cities during the Late Middle Ages: Employment, Recruitment, and Support', in: Universities and Schooling in Medieval Society, ed. W.J. CouRTENAY a.o., (Leiden, 2000), p. 49ff.; E. IsEnMAnN, 'Reichsrecht und Reichsverfassung in Konsilien reichsstädtischer Juristen (15.-17. Jahrhundert)', in: Die Rolle der Juristen bei der Entstehung des modernen Staates, ed. R. ScHNUR, (Berlin, 1986), p. 560.; H.G. WALTHER, 'Italienisches gelehrtes Recht im Nürnberg des 15. Jahrhunderts', in: Recht und Verfassung im Übergang vom Mittelalter zur Neuzeit, Teil 1. Bericht über Kolloquien der Kommission zur Erforschung der Kultur des Spätmittelalters 1994 bis 1995, ed. H. BOOCKMANN a.o., (Göttingen, 1998: Abhandlungen der Akademie der Wissenschaften in Göttingen, Philologisch-historische Klasse, Dritte Folge 228), p. 227..

18 For Cologne see STEIN, Akten 1, p. CXVIIIff.; for Nuremberg M.J. SCHMIED, Die Ratsschreiber der Reichsstadt Nürnberg (Nürnberg, 1979: Nürnberger Werkstücke zur Stadt- und Landesgeschichte 28), p. 63ff.

19 Modern jurisprudence is quite aware of the fact that judges cannot stick to what a law meant when it was written down sometimes decades ago. Instead, the German Federal Constitutional Court (Bundesverfassungsgericht) gives preference to what is called a 'systematic interpretation' of old laws (which leads to the 'adaptation' of the content of old laws to modern problems). Peter Raisch cites the German Federal Constitutional Court: "Die Auslegung einer Gesetzesnorm kann nicht immer auf die Dauer bei dem ihr zu ihrer Entstehungszeit beigelegten Sinn stehenbleiben” and ads "[D]er systematischen Auslegung wird also jedenfalls bei älteren Gesetzen - eine Präferenz zugebilligt”; P. RAIsCH, Juristische Methoden. Vom antiken Rom bis zur Gegenwart (Heidelberg, 1995), p. 150. That reading, not writing, is the decisive process in which a text is attributed a specific meaning - a concept quite common among scholars of literary studies, can only be mentioned here; W. IsER, Der Akt des Lesens (München, 1994). 
wish to speculate on what made the council act this way. Seen from the perspective of the text, one can argue that the statutes are not depicted as a child of the city council's might and power - something which in other circumstances the council is eager to preserve and put forward. The slightest change of the text must be approved by all the institutions mentioned. It should be noted that there were no regular gatherings of the council, council of the 44, the high court and judge. Rather, extraordinary gatherings took place only every ten or fifteen years during the $15^{\text {th }}$ century ${ }^{21}$. Mentioning all these institutions and implementing the scribes as watchdogs leads to the impression that the links between council and text were not very tight. Thus, the text became more or less an independent product, written and guarded by several different persons and institutions.

\section{$5 \quad$ Trust in Writing 2: Being able to point to something}

\section{1 'To refer to' - communicating by reference}

No doubt, significant regulations as to how to manage the city were written down and put together in the statutes of 1437. But like almost all constitution-like texts, the task of such a document may not primarily be to settle certain matters once and for all. And looking at the incoherence of the presented text and the lack of properly legitimised institutions of interpretation, this seems to be even more true of the Cologne statutes.

An important issue is that such a text may be used as a reference; and, as is well known, if you can point to a good reference an argument is made stronger. But what does 'pointing to a reference' really mean? It was just argued, that the content of the text did play a role, but in our case it can hardly be said that it played the most important one. Having a reference to point to not only makes an argument stronger because what you put forward here is already written there. From the viewpoint of the structure of communication - and this is the perspective of the paper - the fact that you can point to something, the pointing-out itself, is the decisive element in the way writing is used here.

The point I want to make is in looking at the way in which people communicate, a certain change is taking place as soon as texts of the kind mentioned are involved. Without such a reference, what might have been a bipolar conversation between two people such as ' $\mathrm{I}$ am right and you are wrong', now suddenly involves a third party: 'I am right and you are wrong - and the text says so as well ${ }^{22}$. What is gained in this triangular type of communication is a kind of common ground. Again though, not in respect of the content of the text - which, of course, is a matter of debate. Although hardly noticing it, in their controversy both agree on two things: They agree that it is important to refer to the text, and that in consequence the text as such is relevant.

21 If I am not mistaken, 1420, 17 years before the statutes were passed, was the last time all these institutions met; STEIN, Akten 1 Nr. 111, pp. $286 f$.

22 Discussing the difference between a verbal agreement/promise and a written contract, K. EHLICH, 'Funktion und Struktur schriftlicher Kommunikation', in: Schrift und Schriftlichkeit / Writing and Its Use. Ein interdisziplinäres Handbuch internationaler Forschung / An Interdisciplinary Handbook of International Research 1, ed. H. GÜNTHER a.o., (Berlin - New York, 1994: Handbücher zur Sprach- und Kommunikationswissenschaft 10), p. 25., says that thus one gains an external 'institution of appeal': "Die Schriftform entbindet das Versprechen aus der unmittelbaren Sprechsituation. Sie objektiviert es und erleichtert so die Garantierung durch die Einrichtung einer externalisierten Appellinstanz.” 
Before discussing the consequences on a more general scale, let me firstly address another point. 'I am right, and you are wrong, and the master Tailor says so as well'. This might also be considered a triangular type of communication. So what, then, is the difference about pointing to a text instead of pointing to a person? Medieval society, as is quite well known, is structured in ranks and groups. Each person belongs to one or more of these groups (families, guilds, fraternities ...), which in turn take certain positions in relation to other groups and persons. Of course, you might refer to a master Tailor in order to strengthen your position, but most likely, everyone knows that you are member of the same guild or he is the husband of your niece. In such a society, during conflict, even kings rapidly belonged to one side or the other ${ }^{23}$. Maybe, that is why during the middle ages, most of the time mobilising persons in your favour does not take on the form of 'pointing-out-to-someone', but is put forward in the form of a request or plea. It is, for instance, quite common for city courts to mitigate a verdict because a guild or high-ranked persons pleaded for those convicted. This is of course helpful, especially if it is a guild of knifesmith which gather in front of the city hall to 'intercede' for one of its members, as was the case in Nuremberg in $1503^{24}$. No doubt, this had positive consequences in respect of the verdict waiting for the gallows. However, from the perspective of the society as a whole, pointing-out to persons - and that means 'supporters' most of the time -, bears the risk of fuelling a conflict ${ }^{25}$.

This is different with texts, at least with text that gained a certain quality. In his book 'Das kulturelle Gedächtnis', Jan Assmann describes how, in ancient Egypt, texts became 'canonised'. Firstly, it is important that a canonised text forms a certain unity: Once it is finished, it is finished forever, and it is not possible to add or take away any parts of the text. While what Assmann called 'holy text' has to be repeatedly cited in ritualistic performances, and thus is not open to interpretation, the opposite is true of canonised texts. They represent normative values of a given society and all around canonised texts special institutions emerge, responsible for the interpretation of such texts ${ }^{26}$.

23 K.J. LeYSER, Herrschaft und Konflikt. König und Adel im ottonischen Sachsen (Göttingen, 1984: Veröffentlichungen des Max-Planck-Instituts für Geschichte 76), p. 157ff. (engl.: Rule and Conflict in an Early Medieval Society: Ottonian Saxony), has shown that it is difficult for Ottonian kings to act as a judge even in local disputes, because they somehow are involved in the conflict.

24 The council took on the challenge, sent the knifesmith back because it was not allowed to come to the town hall in great numbers. They had to send nine virgins instead, and then their two companions were let free. C. HEGEL, 'Die Chroniken der deutschen Städte vom 14. bis ins 16. Jahrhundert, Bd. 11: Die Chroniken der fränkischen Städte, Bd. 5 Nürnberg', (Leipzig, 1874), p. 661.. Numerous examples can be find in K. SCHUÉ, Das Gnadebitten in Recht, Sage, Dichtung und Kunst. Ein Beitrag zur Rechts- und Kulturgeschichte, 'Zeitschrift des Aachener Geschichtsvereins' 40 (1918); see also P. SCHUSTER, Eine Stadt vor Gericht. Recht und Alltag im spätmittelalterlichen Konstanz (Paderborn, 2000), p. 273ff.; for $16^{\text {th }}$ and $17^{\text {th }}$ centuries see K. HÄRTER, 'Social Control and Enforcement of Police-Ordinances in Early Modern Criminal Procedure', in: Institutionen, Instrumente und Akteure sozialer Kontrolle und Disziplinierung im frühneuzeitlichen Europa, ed. H. SCHILLING, (Frankfurt/M., 1999: Ius Commune Sonderheft 127), p. 39ff.

25 F.-J. ARLINGHAUS, 'Gnade und Verfahren. Kommunikationsmodi im spätmittelalterlichen Stadtgerichtsverfahren', in: Interaktion und Herrschaft. Die Politik der frühneuzeitlichen Stadt, ed. R. SCHLÖGL, (Konstanz, 2004: Historische Kulturwissenschaft 5), p. $137 \mathrm{ff.}$.

26 J. Assmann, Das kulturelle Gedächtnis. Schrift, Erinnerung und politische Identität in frühen Hochkulturen (München, 1992), p. 91ff. 
Admittedly, ancient Egypt is not Cologne. But Assmann's analysis highlights that there are at least two different sorts of texts: the holy ones and his 'canonised ones'. In my opinion, only the latter can achieve a kind of independence. An independence that does not allow anyone to have direct access to the texts, but without reserving it for 'holy' rituals only. Please remember that the Cologne statutes of 1437 were the first of that kind in this city to remain in force forever. The text could only be changed if all major institutions of the city - the city council, the council of the 44, and the jury of the high court - came together and agreed on doing so. Meanwhile, none of the named institutions was in direct control of how the text should be understood; it is the two city scribes (Asmann's 'special institutions') who had to take on that task. Ancient Egypt is not Cologne, but the similarities are striking. According to our interpretation of the prologue, the statutes of 1437 were not only symbolically charged, but 'canonised', or, as I like to put it, constructed as something different and independent, not ascribed to or belonging to a certain group or person.

That brings us back to the reference-argument put forward above. Something you want to refer to has to be considered different and independent, and must exist in its own right. A written text - at least in premodern times - is not per se to be considered independent, as Assmann's differentiation between 'holy' and 'canonised' texts has shown. They do have the potential to become something different, but at least for late medieval Cologne, this required a certain 'preparation' of the text given.

The statues of 1437 were discussed here at length, because in their prologue they explicitly 'talk' about their 'canonisation'; from the viewpoint of the text, it can be read as a kind of 'declaration of independence'. That, of course, does not mean that all the means employed here are necessary to transform a text into an independent point of reference. The 'Verbundbrief' was also passed by an extraordinary gathering that may have taken place for the first time in Cologne history: The gathering of all 22 'Gaffeln', of which some of them formed anew after the revolt of 1396 . While all other constitutional-like documents of the city before that time ought to be renewed every ten years, the Verbundbrief was the first that claimed eternal validity ${ }^{27}$. As an example however, there were no scribes or other personnel mentioned to watch the text. Instead, the city had to attach its 'great seal' to the 'letter', and all the 22 Gaffeln had to do so as well. What is more: every Gaffel got a copy of the Verbundbrief, if one got lost, an exact copy had to be written and all 22 guilds had to add their seals to this copy ${ }^{28}$. The text, in this case is 'defended' not by the scribes, but by a certain mixture of authentication and publicity.

There are definitely more and other ways to canonize a text. I would just like to mention one more: Time. As Jan Assmann already explained, in an endless stream of tradition ("Traditionsstrom"), some texts are copied more often than others. After a while, some of these are

27 U. HEPPEKAUSEN, Die Kölner Statuten von 1437 - Ursachen, Ausgestaltung, Wirkung, 'Geschichte in Köln' 45 (1999), p. 7f.

28 Ouch hain wir oeverdragen, dat wir eyn rait zerzijt der stat van Coelne ind wir alle anderen ampten ind gaffelen vurschreven, die yre segele an desen brief gehangen haent, as mallich van uns deser verbontbrieve eynen mit der stede meysten segele und unser alre ampte und gaffelen segelen besegelt haven und in unser gewalt behalden solen ...; HuISKES, 'Verbundbrief'., § 14, pp. 13. The same article holds the regulations concerning how to proceed when one 'Verbundbrief' got lost or burned. 
attributed a special 'rank', they become 'classics' - a first step to canonisation ${ }^{29}$. The Saxon Mirror may be a medieval example of a text that became canonised over time. Written between 1220 and 1230 by Eike van Repgow as a private compilation of laws, the text, from which 315 manuscripts have survived ${ }^{30}$, some lavishly illustrated ${ }^{31}$, gained an extraordinary status during the late middle ages, being used by the juries of cities like Magdeburg and Halle, for instance, even though they should only have applied the cities statutes ${ }^{32}$

\subsection{Text-reference in practice: A rebellious councilman}

A conflict that arose in 1451 between the councilman and member of the jury of the archbishops' high court, Herman Scherfgijn, and the city council, may illustrate how such texts play their role in communication of that time. In that year, a resolution of 1446 was abolished which denied any jury-members to become members of the council ${ }^{33}$. The new regulation of 1451 was not just another ordinary decision of the city council, which appears like little notes in the councils protocol books, without naming any further institutions and mostly without taking alteration of the decision as a theme. Instead, because of its importance the city council, together with the council of the 44, took part in the decision and it is emphasised that no one is allowed to change a word of this resolution without the approval of the two institutions named ${ }^{34}$. That this was an extraordinary text is highlighted by the fact that it did not only appear in the councils protocol book, a paper volume, but was also written down on the expensive parchment of the oath book as a kind of amendment ${ }^{35}$.

So, in 1451, jury members of the archbishops High Court could again be elected as councilmen by their Gaffeln, but had to leave the council as soon as items that concerned the court or its jury were discussed. Scherfgijn, who before 1446 had regularly been a member of the council $^{36}$, was now once more elected by his guild 'Eisenmarkt', but when he had to swear his oath, refused because he could not accept the regulation that obliged him to leave the council as soon as the theme 'high court' was on the agenda.

In Cologne, as it was in so many other cities, once elected, it was not permitted to decline becoming a councilman ${ }^{37}$. On the other hand, no one could be admitted to the council who

29 Assmann, Das kulturelle Gedächtnis, p. 91ff.

30 P. JOHANEK, 'Rechtsschrifttum', in: Die deutsche Literatur im späten Mittelalter (1250-1370), ed. I. GLIER, (München, 1987: Geschichte der deutschen Literatur von den Anfängen bis zur Gegenwart 3,2), p. 408.

31 See the 'Wolfenbütteler Bilderhandschrift'; R. SchmidT-WIEGAND (Ed.), Der Sachsenspiegel. Die Wolfenbüttler Bilderhandschrift Cod. Guelf. 3.1 Aug. $2^{\circ}$. Faksimileband, (Berlin, 1993), and the excellent online version of that manuscript http://www.sachsenspiegel-online.de/.

32 JoHANEK, 'Rechtsschrifttum', p. 410.. Altogether, things are a more complicated. Johan von Buch, who wrote his important gloss on the Saxon mirror around 1330, pretends that he has seen a manuscript of the 'Mirror', sealed by the emperor - which definitely never existed. So according to von Buch, the status of the 'Sachsenspiegel' is the result of an emperors act, while in fact it is the outcome of an evolutionary process over time; JOHANEK, 'Rechtsschrifttum', p. 423..

33 StEIn, Akten 1 , Nr. 152, p. 319, $9^{\text {th }}$ December 1446.

34 Ind dat verdrach is geschiet durch unse heren, alle reede ind die 44 ind sall ouch nymant lengen noch kurten buyssen alle reede ind die 44 ...; ebd. , Nr. 173, p. 370ff., quotation p. 372, ende of 1451.

35 Ebd. , Nr. 173, p. 370.

36 HERBORN, Führungsschicht, p. 590.

37 See text given below in fn. 45. 
had not sworn his oath. Even worse, Scherfgijn was a man of good reputation, belonging to one of the most important families of the city. His guild, Eisenmarkt, was the Gaffel of the wealthy Cologne merchants, with considerable influence; this guild alone provided more than $50 \%$ of the Cologne mayors between 1399 and $1450^{38}$.

Scherfgijn, when asked about the reason of his objection, said that his conscience did not allow him to do so, and pointed out to the Verbundbrief. He paraphrased paragraph two, which reads that there should henceforth only be one, undivided council. If, he concluded, he had to leave the council, this would go against the Verbundbrief ${ }^{39}$. He would be pleased to swear his oath, but only if the part in question - leaving the council when talking about the high court - would be left out.

The council ordered him to go home and think things over. After a while, the city authority sent a deputation of councilmen to his house - a quite common procedure - to ask him if he had changed his mind. Scherfgijn stuck to his position and was thus ordered to come to the council again. In front of all councilmen, Scherfgijn was asked again, if he now was prepared to swear his oath. In his reply, Scherfgijn gave a long explanation, without saying anything new. In return, the council now made him read parts of the Verbundbrief - not the second paragraph, but paragraph one, which says that the council has all the power within the city and every citizen has to be obedient to $i^{40}$. Subsequently, the rebellious councilman also had to read the new regulation of the oath in dispute, which states that a nominated councilman who does not swear the oath should not be allowed to join the council ${ }^{41}$. The rest of the story is short: He should consider, the council told Scherfgijn, that the whole council and the council of the 44 had passed this regulation, and if he does not want to swear his oath, they will tell his Gaffel to elect another one. Scherfgijn in turn thanked the council and left the town hall.

After all these gatherings and negotiations between the Cologne council and the councilman elect of the Gaffel Eisenmarkt, this is quite far from the 'show down' one might have expected. No kneeling down or other rituals of pardon $^{42}$ by the rebellious Herman Scherfgijn, no sentencing, not even the threat of punishment because he did not obey the orders of the city council. Certainly, given the background of Scherffgijn described above, it is fair to say

38 HERBORN, Führungsschicht, p. 324ff. and p. 590.

39 ... hait sich her Herman des eydtz geweigert zo doin, bedunckende, dat he des van consciencien weigen nyet doin moige na luyde des verbuntbrieffs, daeynne geschreven stae, dat geyn gedeilt ind gescheiden rait syn soele; seulde he dan uyss raitzstat gain, as van der alder off nuwer scheffenen sachen yedt gesprochen seulde werden, dat were weder den verbuntbrieff; STEIN, Akten 1 , Nr. 174, p. 373. For the mentioned part of the Verbundbrief, see HuIsKEs, 'Verbundbrief'., § 2, p. 7.

40 The councilmen ... haint her Herman doin leisen dat punte des verbuntbrieffs, dat eyn yeder burger den rait moegich ind meichtich sall laissen sitzen; STEIN, Akten 1 , Nr. 174, p. 374. See HuISKES, 'Verbundbrief'., $\S 1$, p. $6 f$.

41 ... sy haint yem ouch doin leisen die partikell des vurs. verdraigs, as wer den eydt nyet doin weulde, dat man den darvur kennen ind nyet zo raide soele laissen gain; STEIN, Akten 1 , Nr. 174, p. 374. 'Vurs. verdraigs' refers to the new regulations of the oath; see STEIN, Akten 1, Nr. 173, p. 374.

42 There was a certain place - behind the Ratsmeister - in the council's chamber where people bagged the council for pardon; see for instance; M. HuISKEs (Ed.), Beschlüsse des Rates der Stadt Köln 1320-1550, Bd. 1: Die Ratsmemoriale und ergänzende Überlieferung 1320-1543, (Düsseldorf, 1990: Publikationen der Gesellschaft für Rheinische Geschichtskunde 65), Nr. 1458/13, $13^{\text {th }}$ October 1458. Sometimes they had to kneel down; HuISKES (Ed.), Beschlüsse, , Nr. 1480/12, p. 629, 24 ${ }^{\text {th }}$ May 1480. 
that neither side was interested in an escalation of the conflict. Still, in such a conflict, the authority and honour of the city council was at risk - and so was Scherffgijn's.

What was the function of the texts here? First, a closer look at the content of the texts will show that it is at least questionable that they suited the given situation. It is true, paragraph two, to which Scherfgijn pointed out, wants one undivided council, but its real aim was to abolish the two-chamber-system still in existence in 1396, and it clearly said so ${ }^{43}$. What is more: Since the $14^{\text {th }}$ century, part of the oath of every councilmen has been that he had to temporarily leave the sitting if the council dealt with things concerning his relatives or his guild $^{44}$, and none - not even Scherfgin - complained about it or found it contradictory to the named paragraph of the Verbundbrief.

Instead of questioning Scherfgijn's reading of the Verbundbrief, the council answered with paragraph one of the Cologne 'constitution'. This in itself is somewhat strange, since paragraph six suits exactly the situation given. It says that the councilman elect, who constantly refuses to accept his election, should be locked up in one of the city towers for one year $^{45}$, whereas paragraph one unspecificly wants that every citizen should accept the council as the institution that ruled the city ${ }^{46}$.

Looking closely at the paragraphs, there would have been very good reason for discussion if the texts brought in had really suited the given controversy. It is remarkable that such a discussion did not take place. True, we do not know every word that was spoken during the gathering of the city council, however, the protocol book (Ratsmemoriale) does report in short some of Scherfgijn's statements, and the orders of the council as a reply. But even if there would have been a discussion about how to understand the cited statutes, it is quite telling that this was not worth reporting ${ }^{47}$. Instead, the Ratsmemoriale gives detailed information on how, when, and by whom a text was introduced into the dispute.

43 To paraphrase the following: 'There shall be only one undivided council sitting together that means that furthermore there should not be a small (enge) and a big (wijdth) one in Cologne, as it has been in former times'. Ouch so sall vortme eyn unverscheiden, ungedeilt rait sijn und sitzen gemeynlichen bijeynanderen in eyme rade; dat is also zu verstain, dat geyn enge noch wijdth rait bynnen Coelne me sijn noch sitzen ensall, as vurzijden geweist und gesessen hait; HuISKES, 'Verbundbrief'., § 2, p. 7.

44 Vort were sache, dat eynghe clage off sache vior den rait queme antreffende eynichs raitmans ampten, gaffel, vader, moyder, suster, broyder, heren, eydom, wijff off kynt, so sal die raitman ussgain als langhe, bis die sache volendt is; STEIN, Akten 1 ; Nr. 62, § 12, p. 214, oath book (ca. 1398-1400) and Nr. 159, Art. 1, § 12, p. 327, oath book, around 1450.

... so wilch man van unss ampten, gaffelen und gemeynden vurschreven also zo rade gekoiren worden is, [this person] sall darzo gehorsam sijn und zo rade sitzen sonder wederreide .... Ind were sache, dat eman van uns darenboyven nyet gehoirsam enwere noch zo rade sitzen enweulde, as eme geboiden wurde eynss, anderwerf und dirdewerf, so wie sich dat darzo heyscht und gebuert, dat die ungehorsame asdan eyn jair lanck unden in eyme der stede torne lijgen sall ...; HUISKES, 'Verbundbrief'., § 6, p. 10, Verbundbrief.

46 In deme yrsten so hain wir alle ampte und gaffelgeselschaffen ... geloift und uns verbonden ...eyme rade zerzyt der stat van Coelne bystendich, getruwe und hoult zo syn ind yn moegich und mechtich laissen bliven und sitzen alre sachen; ebd., § 1, p. 6, Verbundbrief

47 I am not saying that the discussion of the content of a text in that environment in general did not take place. It is just that this dispute, which does without discussion of the content, clearly brings out the referencepoint aspect of a controversy - a point that is somehow 'hidden' behind the discussion of content in other examples. 
Content, of course, did matter, especially since the council wisely selected a paragraph that didn't intensify the conflict. The decisive advantage of introducing a text in this controversy though, cannot be seen in re-loading content that everybody in the council was more or less familiar with ${ }^{48}$. In referring to the text, Scherfgin had not only 'protected' himself by pointing out to the widely accepted values, but in paraphrasing the Verbundbrief, a third and independent 'party' started 'talking' and taking part in the dispute. This, in turn, widened the space of communication, because aside from the ad hoc formulated speeches of the people present, statements considered independent of any personal relation, took part in the discourse $^{49}$. It is logical, or at least reasonable, that the city council could not answer this with a simple resolution, but had to mobilise a text as well, in order not to leave this space of communication blank. References to texts of this status are best answered with references to texts.

It is not far-fetched that Scherfgin would easily have found people to support him and his position - his guild Eisenmarkt, which elected him, or councilmen who like him were members of the high court. That he did not see the need to call upon these supporters, but considered it sufficient to start a dispute with the city council, 'supported' only by a text, is in itself remarkable ${ }^{50}$.

A closer look on how the two texts, the paragraphs of the Verbundbrief and the council resolution concerning the jury of the High Court, were implemented during the sitting in the city hall may show in detail the advantage of introducing a text in the discussion. The decisive point is that not one of the city scribes, the protonotarius, or one of his secretarii, took on the task to read; the council wanted Scherfgin to read out the two texts. Things do get complicated here. Scherfgin had to recite that the Cologne council had all power in the city a point no one questioned - and that the members of the jury should leave the city council in certain circumstances - a point strongly opposed by the reader of the text. From Scherfgin's point of view, he just recited texts that reflected his opinion only in part. Would that undermine his position? From the council's point of view, a rebellious councilman had to read out his resolutions aloud in front of all members of the council. Could that not be seen as a sign of giving up or at least consent? There is, of course, a certain ambiguity here, because it is not clear how or how far one could identify the reader of the text ${ }^{51}$, and this ambiguity seemed to be quite helpful in finding a 'soft' solution of the conflict given. The texts, thus, forms a cru-

48 At least parts of the Verbundbrief were read out after each election of a new council; STEIN, Akten 1 , No. 192, p. 384 (ca. 1460). Every Gaffel had such a document, and it is quite likely that it was read out regularly; R. GIEL, Politische Öffentlichkeit im spätmittelalterlich-frühneuzeitlichen Köln (1450-1550) (Berlin, 1998: Berliner Historische Studien 29), p. 276. Writing here becomes the 'institution of appeal' Konrad Ehlich wrote about; see citation above in fn. 22.

50 There quite a few examples of guilds supporting their councilman elect if he was rejected by the council; see GIEL, Politische Öffentlichkeit, p. 253ff.

51 This is a general phenomenon when texts are read out in a performance: „Bei der Frage, ob und inwiefern sich der Vorleser von der textuellen persona in der Performanz unterscheiden ließ, steht man wieder vor dem Wettbewerb zwischen schriftlichen und mündlichen Autoritätsansprüchen, dem des Textes und dem des Vorlesers, da es ja der Vorleser nicht zuletzt ist, der textuellen persona ihre Präsenz verleiht“;F.H. BÄUML, 'Autorität und Performanz: Gesehene Leser, gehörte Bilder, geschriebener Text', in: Verschriftung und Verschriftlichung. Aspekte des Medienwechsels in verschiedenen Kulturen und Epochen, ed. C. EHLER a.o., (Tübingen, 1998: ScriptOralia 94), p. 260.. 
cial part of a performance ${ }^{52}$ that made it possible to demonstrate the authority of the council, without damaging the honour of the rebellious councilman ${ }^{53}$.

\section{Late-medieval text-status compared}

In contrast to late-medieval practices, which required a certain 'manufacturing of independence' of a text before it could serve as point of reference, in present or 'modern' society, it seems that even price-tags on a chocolate are attributed an independent status and could function as reference ${ }^{54}$. May that be an exaggeration, it obvious that, at least as far as constitutions and law books are concerned, in our days texts such as these reclaim per se an independent status, and are considered trustworthy ${ }^{55}$. Without any seals or special gatherings necessary, today's printed (law) texts in general function like 'social institutions ${ }^{, 56}$, and it is almost natural to point to them to foster a certain argument ${ }^{57}$. Thus, it is no longer necessary to 'manufacture' the independence of a text, as was the case the Cologne statutes.

The contrary seems to be true for early medieval texts, especially those of the $10^{\text {th }}$ century. This is, of course, a time where in German speaking countries, written documents were seldom to be seen and royal/imperial charters are the exception to the rule ${ }^{58}$. Peter Rück calls royal charters a work of art ('Kunstwerk'): The way the scripture is distributed over the parchment, the scripture itself together with the seal, and the dimensions of the document highlight that their main purpose was to be shown rather than to be read, and Rück explicitly says so $^{59}$. This is especially true for Ottoman charters, whose writing is described as 'ungainly' (ungelenk) and 'hard' ${ }^{60}$. As a whole (size, symmetric distribution of writing and

52 With reference to John L. Austin, Egidi et al. define performance as an action that gains its specific sense while it is taking place. It cannot be reduced to the words spoken or the texts read out. "Performanz [wird] als ein originärer, in seinem Vollzug sinnkonstituierender Akt bestimmt, der nicht auf die Aus- bzw. Aufführung eines bereits existierenden Textes ... reduziert werden kann”; M. EGIDI a.o., 'Riskante Gesten. Einleitung', in: Gestik. Figuren des Körpers in Text und Bild, ed. M. EGIDI a.o., (Tübingen, 2000: Literatur und Anthropologie 8), p. 26.

53 In similar situations members of the city council had to ask for apology and to humble themselves while doing so; see fn. 42.

54 See the bon mot of Niklas Luhmann at the beginning of this article.

55 M.T. Clanchy, From Memory to Written Record. England 1066-1307, Oxford, 1979; ${ }^{2} 1993$, p. 294, sees modern schooling and the constant use of documents in every-day life responsible for the present 'trusting in writing'.

56 I owe this term to Rudolf Schloegl, Konstanz, and I like to thank him for answering my questions concerning that point.

57 That printing played a key role in this statutes of modern texts is obvious, but cannot be discussed here; see recently E. Esposito, Soziales Vergessen. Formen und Medien des Gedächtnisses der Gesellschaft. Mit einem Nachwort von Jan Assmann (Frankfurt/M., 2002), p. 187ff., who, referring to Ong, highlights that with printing the discourse becomes 'a kind of thing' (p. 188).

58 P. RÜCK, 'Die Urkunde als Kunstwerk', in: Kaiserin Theophanu. Begegnung des Ostens und Westens um die Wende des ersten Jahrtausends. Gedenkschrift des Kölner Schnütgen-Museums zum 1000. Todesjahr der Kaiserin, ed. A.v. Euw a.o., (Köln, 1991), p. 311..

59 The charter of German kings and emperors were "in erster Linie zum Anschauen, und erst in zweiter Linie zum Lesen bestimmt”; ebd..

60 B. BISCHOFF, Paläographie des römischen Altertums und des abendländischen Mittelalters (Berlin, 1986: Grundlagen der Germanistik 24), p. 161. 
signs), the charter appears more like a poster than a written document ${ }^{61}$. The text itself, as we learn from Heinrich Fichtenau, was not only designed to be read aloud, but also to be recited and declaimed, getting close to how liturgical texts were read out ${ }^{62}$.

Altogether, this indicates that the way these charters were presented and recited was quite different from scanning the document silently, as we would today. The charter itself already tells us that the way it was used took on the form of a performance ${ }^{63}$. So what is the difference compared to the use of texts in the $15^{\text {th }}$ century? When in a ceremony that evokes the sacredness of kingship, sometimes within a church, the king marks the charter with a strike (Vollziehungsstrich) and personally orders to fix his seal with his picture on the sacra pagina, much more than an independent object, the charter becomes a representative of the issuer. Thus, it seems that is how the 'documents' were 'read'. As Ratpert from S. Gall reports, Louis the Pius, who was handed over a privilege of his father for confirmation, took a close look at the seal, then kissed it and handed the charter to the bystanders, asking them to follow his example and honour it the same way ${ }^{64}$. Not all charters, not even royal ones, were kissed, of course. But this example, together with other ${ }^{65}$, indicates that writing did not exist by its own right, but person, parchment and performance were closely linked.

Is this only true for German royal or imperial documents with their prestigious design? While trust in the legal status of a document is not the same as trust in writing as such, it is fair to say that the first prerequisites the second, so it may serve as an indicator here. As is well known, not the charter, at least not the charter alone, but testimonies and the widespread knowledge proved a legal transaction of that time ${ }^{66}$. Even in an urban environment, rituals

61 “Die Forderung nach Symetrie macht aus dem Handschreiben ein Plakat.” “Aus den langen Präsentiertischen urkundlicher Schriftlichkeit werden hochragende romanische Textfassaden”; RÜCK, 'Theophanu', p. 333..

62 He called the way charters were read out “außerliturgisch-urkundliche[s] Rezitativ”; H. FICHTENAU, 'Bemerkungen zur rezitativischen Prosa des Hochmittelalters', in: Beiträge zur Mediävistik. Ausgewählte Aufsätze 1, ed. H. FICHTENAU, (Stuttgart, 1975), p. 145ff., expression p. 150.

63 H. KelLER, 'Ottonische Herrschersiegel. Beobachtungen und Fragen zu Gestalt und Aussage und zur Funktion im historischen Kontext', in: Bild und Geschichte. Studien zur politischen Ikonographie. Festschrift für Hansmartin Schwarzmaier zum fünfundsechzigsten Geburtstag, ed. K. KRIMM a.o., (Sigmaringen, 1997), p. 3ff.; H. KELLER, 'Otto der Große urkundet im Bodenseegebiet. Inszenierungen der ,Gegenwart des Herrschers' in einer vom König selten besuchten Landschaft', in: Mediaevalia Augiensia = Forschungen zur Geschichte des Mittelalters. Veröffentlichungen des Konstanzer Arbeitskreises für Mittelalterliche Geschichte aus Anlaß seines fünfzigjährigen Bestehens 1951-2001, Bd. 3, ed. J. PETERSOHN, (Stuttgart, 2001), p. 205ff.

Elsewhere, referring to another episode, Hagen Keller explicitly wrote that the 'act of publishing' might have evoked the 'presence of the absent king'; ebd., p. 242..

66 In his book, Michael Clanchy gives a prices analysis of the transformation from 'memory' to 'written record'; M.T. Clanchy, From Memory to Written Record. England 1066-1307 (Oxford, 1993), p. 253ff., pp. 293ff.; already in the introduction (p. 2). For Germany, Peter Johanek stated that it was "die Rechtshandlung und ihre Publizität”; P. JOHANEK, 'Zur rechtlichen Funktion von Traditionsnotiz, Traditionsbuch und früher Siegelurkunde', in: Recht und Schrift im Mittelalter, ed. P. CLASSEN, (Sigmaringen, 1977: Vorträge und Forschungen 23), p. 155.. Examples of the used - or better: unused - charters in legal conflicts even between bishops and kings give K. HeIDECKER, 'Communication by Written Texts in Court Cases. Some Charter Evidence (ca. 800 - ca. 1100)', in: New Approaches to Medieval Communication, ed. M. MosTERT a.o., (Turnhout, 1999: Utrecht Studies in Medieval Literacy 1), p. 101ff. 
like the effestucatio, the handing-over of a stern, were more important for the change of ownership than an entry in the 'land register' ${ }^{67}$. And even in this context, written documents are more to be seen as part of a ceremony than as independent points of reference. "In the rare instances where the conveyance appears to be made by the written document itself," Michael Clanchy writes, "we should probably assume that the document is serving the ancient function of a symbolic object, rather than being considered primarily for its content in a modern literate way.",68

During the $10^{\text {th }}$ and $11^{\text {th }}$ centuries as well as in our example from the $15^{\text {th }}$ century, written texts form part of a kind of performance. The decisive difference is that while during the High Middle Ages charters were used as symbols and / or as representatives of absent persons, texts like the Verbundbrief appear on stage as a third party ${ }^{69}$. While the first is, or is close to a ritual (e.g. evoking the presence of the absent), the second is closer to a staging we see in today's theatres or party conferences.

Going back to the reference-argument, it seems that compared with the High Middle Ages and compared with modern times, sate medieval uses of writing is somewhat caught in-between. While during the first two epochs, the status of writing, although completely different, is quite clear, during the $13^{\text {th }}, 14^{\text {th }}$ and $15^{\text {th }}$ centuries, it is somewhat ambiguous. While on one side, the ever-growing use of writing in every day life - the $12^{\text {th }}$ century may be seen as the watershed - fosters trust in writing, it was still not regarded as a different sphere of communication. While silent reading began to spread and - in combination - the layout of texts changed, table of contents and indices appeared ${ }^{70}$ - in order to name just a few of the changes that took place - the status of writing in general was still different from what we see today: it was not seen as something independent, could not per se serve as point of reference. For instance, the books now designed for 'private' reading, like the books of hours and prayer books $^{71}$ as well as the textbooks of the new 'Devotio moderna' ${ }^{, 72}$, writing (and the pictures it

67 The famous Cologne 'Schreinsbücher', a series of 'land registers', starting in the first half of the $12^{\text {th }}$, were only attributed value of evidence during the $13^{\text {th }}$ century; H. PlaniTZ, 'Konstitutivakt und Eintrag in den Kölner Schreinsurkunden des 12. und 13. Jahrhunderts', in: Festschrift Alfred Schultze, ed. W. MERK, (Weimar, 1934), p. 175ff.. For examples of effestucationes in Cologne see H. PlanITZ a.o. (Ed.), Die Kölner Schreinsbücher des 13. und 14. Jahrhunderts, (Weimar, 1937: Publikationen der Gesellschaft für Rheinische Geschichtskunde 46), p. 2, p. 10 passim. For a quick overview see W. HerBorn, Art. Schreinswesen, -buch, -karte, in: LexMa, Bd. 7 (1995), , col. 1557ff.

ClanCHY, From Memory to Written Record, p. 236. This, of course, has its slash backs on the 'performance' itself, but that cannot be discussed here.

70 See, among others, P.H. SAEnger, Space Between Words. The Origins of Silent Reading (Stanford, 1997: Figurae. Reading Medieval Culture); I. ILLICH, In the Vineyard of the Text: a Commentary to Hugh's Didascalicon (Chicago, Ill. [u.a.], 1993); R.H. Rouse a.o., 'Statim invenire: Schools, Preachers, and New Attitudes to the Page', in: Renaissance and Renewal in the Twelfth Century, ed. R.L. BENSON a.o., (Cambridge/Mass., 1982), p. 201ff.; H.-J. MARTin a.o. (Ed.), Mise en page et mise en texte du livre manuscrit, (Paris, 1990).

71 T. LENTES, 'Prayer Books. Multimedia-Contribution on the CD-ROM', in: Transforming the Medieval World. Uses of Pragmatic Literacy in the Middle Ages, ed. F.-J. ARLINGHAus a.o., (Turnhout, 2004: Utrecht Studies in Medieval Literacy 6b).

72 N. Staubach, 'Text als Prozeß. Zur Pragmatik des Schreibens und Lesens in der Devotio moderna', in: Pragmatische Dimensionen mittelalterlicher Schriftkultur. Akten des Internationalen Kolloquiums des Son- 
accompanied) first of all served as a medium for contemplation, a tool to get closer to God and the Saints. If 'successfully' implied, instead of being a point of reference, writing, as a medium, kind of disappears ${ }^{73}$. This is not only true for religious texts; letters, for instance, were still viewed more as the 'frozen' voice of the sender (and most of the time read out aloud), than as a text that stands on its own ${ }^{74}$. Even the above mentioned Cologne oath books and the Verbundbrief, though they could claim an 'autonomous' status, were probably as often read out during ritual-like acts - like the changing of the councilmen every six month than used explicitly as points of reference.

In its ambiguity, the culture of late medieval writing was more open to make use of different text status. But in contrast to modern times, if a written text should function as a point of reference, it was somehow necessary to mark it as distinct and independent. Therefore, more than today, the written document itself has to give information about its status (sometimes more explicit, like in a prologue of the statutes of 1437, sometimes more implicit, i.e. by the numerous seals and the order to 'publish' it, like the Verbundbrief). Especially in the cities of that time, around such texts, persons of a somewhat extraordinary status - Assmann's 'social institutions, ${ }^{75}$ - emerge, who take on the task to 'guard' the text. One may think of the notaries in Italy ${ }^{76}$, or the city scribes in German speaking territories ${ }^{77}$. Sometimes, like the 'Scheinsmeister' in Cologne, they are the only ones who have full access to the written documents ${ }^{78}$.

\section{Outlook}

Beside the fact that the late medieval city is still a religious community, we should not overlook the very different life forms to be found within the city walls. From the $14^{\text {th }}$ century onwards, numerous revolts may be seen as an indicator of a lack of stability. Establishing certain texts as an independent point of reference in the discourses of that time may have

derforschungsbereichs 231, 26. - 29. Mai 1999, ed. C. MEIER a.o., (München, 2002: Münstersche Mittelalter-Schriften 79), p. 251ff..

73 See LenTES, 'Account books'.; and StAuBAch, 'Text als Prozeß', p. 251ff. (with further readings).

74 H. WENZEL, 'Boten und Briefe. Zum Verhältnis körperlicher und nicht-körperlicher Nachrichtenträger', in: Gespräche - Boten - Briefe. Körpergedächtnis und Schriftgedächtnis im Mittelalter, ed. H. WENZEL, (Berlin, 1997: Philologische Studien und Quellen 143), p. 86ff.

75 See above before fn. 26.

76 For the complex connection between trusting the notary and trusting the document he wrote, see P. SCHULTE, Scripturae publicae creditur. Das Vertrauen in Notariatsurkunden im kommunalen Italien des 12. und 13. Jahrhunderts (Tübingen, 2003: Bibliothek des deutschen Historischen Instituts in Rom 101), p. 27ff. After all, it seems that a strong 'personal' element in the use of writing lasted throughout the middle ages.

77 See, for instance, P. HoHEISEL, Die Göttinger Stadtschreiber bis zur Reformation. Einfluß, Sozialprofil, Amtsaufgaben (Göttingen, 1998: Studien zur Geschichte der Stadt Göttingen 21); M. JuCKER, Vom klerikalen Teilzeitangestellten zum gnädigen Kanzler. Aspekte der spätmittelalterlichen Bildungswege der Stadtschreiber in der Eidgenossenschaft, 'Traverse' 9 (2002), p. 45ff..

78 Only the 'Schreinsmeister' and their scribe were allowed to look up the entries in the 'land registers' (Schreinsbücher). If needed, the citizens only became copies of these entries to present in court; K. MILITZER, 'Entstehung und Bildung von Archiven in Köln während des Mittelalters', in: Archivprozesse. Die Kommunikation der Aufbewahrung, ed. H. PomPE, (Köln, 2002: Mediologie 5), p. 30.; PlANITZ, 'Konstitutivakt', p. $175 \mathrm{ff}$. 
helped to soften the problem. Without reflecting on it, people now differentiated between 'pointing-out' to a text and its content. Thus, 'referring-to' could be seen as the new 'common ground' being introduced into the societies of that time. The specific advantage of this differentiated form of communication is that it puts less weight on the content of a text. This, in turn, allows even fiercer battles on content, because communication as such is not completely at risk - one still agreed that pointing to a certain text is important. Since content is a matter of interpretation, more than what a statute really 'says' was be trusted, but the reference to it. On a more general scale, one may argue that by establishing independent texts that could function as points of reference, late medieval society might have regained a security that may have been lost because of its ever-growing complexity.

\section{Bibliography}

F.-J. ArLinghaus, Gnade und Verfahren. Kommunikationsmodi im spätmittelalterlichen Stadtgerichtsverfahren, in: Interaktion und Herrschaft. Die Politik der frühneuzeitlichen Stadt, hg. von R. ScHLÖGL, (Historische Kulturwissenschaft 5) Konstanz 2004, S. 137-162.

J. Assmann, Das kulturelle Gedächtnis. Schrift, Erinnerung und politische Identität in frühen Hochkulturen, (München, 1992

I. BAUMGÄRTNER, Niederhessen in der Krise? Städtischer Aufruhr im landgräflichen Kassel und im erzbischöflichen Hofgeismar, in: Nordhessen im Mittelalter. Probleme von Identität und überrregionaler Integration, hg. von I. BAUMGäRTNER und W. SCHICH, Marburg 2001, S. 137-170.

F.H. BÄUML, Autorität und Performanz: Gesehene Leser, gehörte Bilder, geschriebener Text, in: Verschriftung und Verschriftlichung. Aspekte des Medienwechsels in verschiedenen Kulturen und Epochen, hg. von C. EHLER und U. SCHAEFER, (ScriptOralia 94) Tübingen 1998, S. 248-273.

B. Bischoff, Paläographie des römischen Altertums und des abendländischen Mittelalters, (2. Aufl., Berlin, 1986: Grundlagen der Germanistik 24).

M.T. Clanchy, From Memory to Written Record. England 1066-1307, (2. überarb. Aufl., Oxford, 1993

B. DReHER, Die Beschwörung der Freiheit. Gemeinde versus Rat 1481/82, 1512/13, 1525, 1680-86, in: Der Name der Freiheit 1288-1988. Aspekte Kölner Geschichte von Worringen bis heute, hg. von W. SCHÄFKE, Köln 1988, S. 445-477.

— (Hg.), Texte zur Kölner Verfassungsgeschichte, (Veröffentlichungen des Kölnischen Stadtmuseums 6) Köln 1988.

M. EgIDI, O. SCHNEIDER, M. SCHÖNING, I. SCHÜTZE und C. TORRA-MATTENKLOTT, Riskante Gesten. Einleitung, in: Gestik. Figuren des Körpers in Text und Bild, hg. von M. 
Egidi, O. Schneider, M. SchÖning, I. SchÜtze und C. TORRA-MATtenKlotT, (Literatur und Anthropologie 8) Tübingen 2000, S. 11-41.

K. EHLICH, Funktion und Struktur schriftlicher Kommunikation, in: Schrift und Schriftlichkeit / Writing and Its Use. Ein interdisziplinäres Handbuch internationaler Forschung / An Interdisciplinary Handbook of International Research 1, hg. von H. GÜNTHER und O. LUDWIG, (Handbücher zur Sprach- und Kommunikationswissenschaft 10) Berlin - New York 1994, S. 18-41.

E. Esposito, Soziales Vergessen. Formen und Medien des Gedächtnisses der Gesellschaft. Mit einem Nachwort von Jan Assmann, (Frankfurt/M., 2002

H. Fichtenau, Bemerkungen zur rezitativischen Prosa des Hochmittelalters, in: Beiträge zur Mediävistik. Ausgewählte Aufsätze 1, hg. von H. FichTENAU, Stuttgart 1975, S. $145-$ 162.

R. GIEL, Politische Öffentlichkeit im spätmittelalterlich-frühneuzeitlichen Köln (1450-1550), (Berlin, 1998: Berliner Historische Studien 29).

K. HÄRTER, Social Control and Enforcement of Police-Ordinances in Early Modern Criminal Procedure, in: Institutionen, Instrumente und Akteure sozialer Kontrolle und Disziplinierung im frühneuzeitlichen Europa, hg. von H. ScHILling, (Ius Commune Sonderheft 127) Frankfurt/M. 1999, S. 39-63.

C. Hegel, Die Chroniken der deutschen Städte vom 14. bis ins 16. Jahrhundert, Bd. 11: Die Chroniken der fränkischen Städte, Bd. 5 Nürnberg, Leipzig 1874.

K. Heidecker, Communication by Written Texts in Court Cases. Some Charter Evidence (ca. 800 - ca. 1100), in: New Approaches to Medieval Communication, hg. von M. Mostert und W.A.I.B.M. Clanchy, (Utrecht Studies in Medieval Literacy 1) Turnhout 1999, S. 101-126.

U. HeppeKausen, Die Kölner Statuten von 1437 - Ursachen, Ausgestaltung, Wirkung, in: Geschichte in Köln 45 (1999), S. 5-13.

—_, Die Kölner Statuten von 1437. Ursachen, Ausgestaltung, Wirkung, (Köln - Weimar Wien, 1999: Rechtsgeschichtliche Schriften 12).

W. Herborn, Die politische Führungsschicht der Stadt Köln im Spätmittelalter, (Bonn, 1977: Rheinisches Archiv 100).

— 1559.

P. HoHeISEL, Die Göttinger Stadtschreiber bis zur Reformation. Einfluß, Sozialprofil, Amtsaufgaben, (Göttingen, 1998: Studien zur Geschichte der Stadt Göttingen 21). 
M. Huiskes (Hg.), Beschlüsse des Rates der Stadt Köln 1320-1550, Bd. 1: Die Ratsmemoriale und ergänzende Überlieferung 1320-1543, (Publikationen der Gesellschaft für Rheinische Geschichtskunde 65) Düsseldorf 1990.

— - Kölns Verfassung für 400 Jahre: Der Verbundbrief vom 14. September 1396, in: Quellen zur Geschichte der Stadt Köln, Bd. 2: Spätes Mittelalter und Frühe Neuzeit (1396 - 1794), hg. von J. DeEters und J. Helmrath, 2. Aufl., Köln 1996, S. 1-28.

I. ILliCH, In the Vineyard of the Text: a Commentary to Hugh's Didascalicon, (Chicago, Ill. [u.a.], 1993

E. ISENMANN, Reichsrecht und Reichsverfassung in Konsilien reichsstädtischer Juristen (15.17. Jahrhundert), in: Die Rolle der Juristen bei der Entstehung des modernen Staates, hg. von R. SCHNUR, Berlin 1986, S. 545-628.

W. ISER, Der Akt des Lesens, (4. Aufl., München, 1994

P. JOHANEK, Zur rechtlichen Funktion von Traditionsnotiz, Traditionsbuch und früher Siegelurkunde, in: Recht und Schrift im Mittelalter, hg. von P. Classen, (Vorträge und Forschungen 23) Sigmaringen 1977, S. 131-162.

— Rechtsschrifttum, in: Die deutsche Literatur im späten Mittelalter (1250-1370), hg. von I. GLIER, (Geschichte der deutschen Literatur von den Anfängen bis zur Gegenwart 3,2) München 1987, S. 396 - 431.

M. JuCKeR, Vom klerikalen Teilzeitangestellten zum gnädigen Kanzler. Aspekte der spätmittelalterlichen Bildungswege der Stadtschreiber in der Eidgenossenschaft, in: Traverse 9 (2002), S. 45-54.

H. KeLLER, Ottonische Herrschersiegel. Beobachtungen und Fragen zu Gestalt und Aussage und zur Funktion im historischen Kontext, in: Bild und Geschichte. Studien zur politischen Ikonographie. Festschrift für Hansmartin Schwarzmaier zum fünfundsechzigsten Geburtstag, hg. von K. KRIMM und H. JoHN, Sigmaringen 1997, S. 3-51.

— - Otto der Große urkundet im Bodenseegebiet. Inszenierungen der ,Gegenwart des Herrschers' in einer vom König selten besuchten Landschaft, in: Mediaevalia Augiensia $=$ Forschungen zur Geschichte des Mittelalters. Veröffentlichungen des Konstanzer Arbeitskreises für Mittelalterliche Geschichte aus Anlaß seines fünfzigjährigen Bestehens 1951-2001, Bd. 3, hg. von J. PETERSOHN, Stuttgart 2001, S. 205-245.

H. Keller und J.W. Busch (Hgg.), Statutencodices des 13. Jahrhunderts als Zeugen pragmatischer Schriftlichkeit. Die Handschriften von Como, Lodi, Novara, Pavia und Voghera, (Münstersche Mittelalter-Schriften 64) München 1991. 
F. LAU, Entwicklung der kommunalen Verfassung und Verwaltung der Stadt Köln bis zum Jahre 1396, (Bonn, 1898: Preisschrift der Mevissen-Stiftung, gekrönt und hg. von der Gesellschaft für Rheinische Geschichtskunde 1).

T. LENTES, Prayer Books. Multimedia-Contribution on the CD-ROM, in: Transforming the Medieval World. Uses of Pragmatic Literacy in the Middle Ages, hg. von F.-J. Arlinghaus, M. Ostermann, O. Plessow und G. Tscherpel, (Utrecht Studies in Medieval Literacy 6b) Turnhout 2004.

K.J. LeYSER, Herrschaft und Konflikt. König und Adel im ottonischen Sachsen, (Göttingen, 1984: Veröffentlichungen des Max-Planck-Instituts für Geschichte 70).

H.-J. Martin und J. Vezin (Hgg.), Mise en page et mise en texte du livre manuscrit, Paris 1990.

A. Мıнм, Vom Dingprotokoll zum Zwölftafelgesetz. Verschriftlichungsstufen städtischer Rechtstradition, in: Schriftlichkeit und Lebenspraxis. Erfassen, Bewahren, Verändern. Akten des Internationalen Kolloquiums (8.-10. Juni 1995), hg. von H. KeLLER, C. MeIER und T. ScharfF, (Münstersche Mittelalter-Schriften 76) München 1999, S. 4367.

K. Militzer, Ursachen und Folgen der innerstädtischen Auseinandersetzungen in Köln in der zweiten Hälfte des 14. Jahrhunderts, (Köln, 1980: Veröffentlichungen des Kölnischen Geschichtsvereins 36).

— Entstehung und Bildung von Archiven in Köln während des Mittelalters, in: Archivprozesse. Die Kommunikation der Aufbewahrung, hg. von H. POMPE, (Mediologie 5) Köln 2002, S. 27-37.

E. PITZ, Bürgereinung und Städteeinung. Studien zur Verfassungsgeschichte der Hansestädte und der deutschen Hanse, (Köln u.a., 2001: Quellen und Darstellungen zur hansischen Geschichte, N.F. 52).

H. Planitz, Konstitutivakt und Eintrag in den Kölner Schreinsurkunden des 12. und 13. Jahrhunderts, in: Festschrift Alfred Schultze, hg. von W. MERK, Weimar 1934, S. 175-202.

H. Planitz und T. BuYKen (Hgg.), Die Kölner Schreinsbücher des 13. und 14. Jahrhunderts, (PGRhG 46) Weimar 1937.

P. RAISCH, Juristische Methoden. Vom antiken Rom bis zur Gegenwart, (Heidelberg, 1995

R.H. Rouse und M.A. Rouse, Statim invenire: Schools, Preachers, and New Attitudes to the Page, in: Renaissance and Renewal in the Twelfth Century, hg. von R.L. BENSON und G. Constable, Cambridge/Mass. 1982, S. 201 - 225. 
P. RÜCK, Die Urkunde als Kunstwerk, in: Kaiserin Theophanu. Begegnung des Ostens und Westens um die Wende des ersten Jahrtausends. Gedenkschrift des Kölner SchnütgenMuseums zum 1000. Todesjahr der Kaiserin, hg. von A.v. EUW und P. SCHREINER, Köln 1991, S. 311-333.

P.H. SAenger, Space Between Words. The Origins of Silent Reading, (Stanford, 1997: Figurae. Reading Medieval Culture).

R. Schmidt-Wiegand (Hg.), Der Sachsenspiegel. Die Wolfenbüttler Bilderhandschrift Cod. Guelf. 3.1 Aug. 2. Faksimileband, Berlin 1993.

M.J. SCHMIED, Die Ratsschreiber der Reichsstadt Nürnberg, (Nürnberg, 1979: Nürnberger Werkstücke zur Stadt- und Landesgeschichte 28).

K. SCHUÉ, Das Gnadebitten in Recht, Sage, Dichtung und Kunst. Ein Beitrag zur Rechts- und Kulturgeschichte, in: Zeitschrift des Aachener Geschichtsvereins 40 (1918), S. 143286.

P. SCHUlte, Scripturae publicae creditur. Das Vertrauen in Notariatsurkunden im kommunalen Italien des 12. und 13. Jahrhunderts, (Tübingen, 2003: Bibliothek des deutschen Historischen Instituts in Rom 101).

P. SCHUSTER, Eine Stadt vor Gericht. Recht und Alltag im spätmittelalterlichen Konstanz, (Paderborn, 2000

G. SCHWERHOFF, Apud populum potestas? Ratsherrschaft und korporative Partizipation im spätmittelalterlichen Köln, in: Stadtregiment und Bürgerfreiheit. Handlungsspielräume in deutschen und italienischen Städten des Späten Mittelalter und der Frühen Neuzeit, hg. von K. Schreiner und U. MeIER, (Bürgertum. Beiträge zur europäischen Gesellschaftsgeschichte 7) Göttingen 1994, S. 188-243.

— Stadtkölnischen Geschichte (13.-17. Jahrhundert), in: Stadtregiment und Bürgerfreiheit. Handlungsspielräume in deutschen und italienischen Städten des Späten Mittelalter und der Frühen Neuzeit, hg. von K. Schreiner und U. MEIER, (Bürgertum. Beiträge zur europäischen Gesellschaftsgeschichte 7) Göttingen 1994, S. 94-119.

N. Staubach, Text als Prozeß. Zur Pragmatik des Schreibens und Lesens in der Devotio moderna, in: Pragmatische Dimensionen mittelalterlicher Schriftkultur. Akten des Internationalen Kolloquiums des Sonderforschungsbereichs 231, 26. - 29. Mai 1999, hg. von C. Meier, V. Honemann, H. Keller und R. Suntrup, (Münstersche Mittelalter-Schriften 79) München 2002, S. 251-276.

W. SteIN, Akten zur Geschichte der Verfassung und Verwaltung der Stadt Köln im 14. und 15. Jahrhundert, Bd. 1, 2 Bde., (Bonn, 1893: Publikationen der Gesellschaft für Rheinische Geschichtskunde 10). 
H.G. WALTHER, Italienisches gelehrtes Recht im Nürnberg des 15. Jahrhunderts, in: Recht und Verfassung im Übergang vom Mittelalter zur Neuzeit, Teil 1. Bericht über Kolloquien der Kommission zur Erforschung der Kultur des Spätmittelalters 1994 bis 1995, hg. von H. Boockmann, L. Grenzmann, B. Moeller und M. Staehelin, (Abhandlungen der Akademie der Wissenschaften in Göttingen, Philologischhistorische Klasse, Dritte Folge 228) Göttingen 1998, S. 215-229.

H. WenZel, Boten und Briefe. Zum Verhältnis körperlicher und nicht-körperlicher Nachrichtenträger, in: Gespräche - Boten - Briefe. Körpergedächtnis und Schriftgedächtnis im Mittelalter, hg. von H. WENZEL, (Philologische Studien und Quellen 143) Berlin 1997, S. 86-105.

K. WRIEDT, University Scholars in German Cities during the Late Middle Ages: Employment, Recruitment, and Support, in: Universities and Schooling in Medieval Society, hg. von W.J. CourTenay und J. MiethKe, Leiden 2000, S. 49-64. 